\title{
KINERJA DINAS PERUMAHAN KAWASAN PERMUKIMAN DAN PERTANAHAN PROVINSI KALIMANTAN TENGAH DALAM PENINGKATAN JALAN LINGKUNGAN DI KOTA PALANGKA RAYA
}

\section{Performance Of Housing Areas Of Residential And Land Area Of Central Kalimantan Province In Improving Environmental Roads In Palangka Raya City}

\section{Laksminarti \\ Laksmi Handayani}

Universitas Muhammadiyah Palangkaraya, Palangka Raya, Central Kalimantan, Indonesia

Email : laksminarti@gmail.com

Keywords :

Perfomance

Enhancement

Environmental road

\section{Kata Kunci :}

Kinerja

Peningkatan

Jalan Lingkungan

\begin{abstract}
Abstrak
Dinas Perumahan, Kawasan Permukiman dan Pertanahan Provinsi Kalimantan Tengah menjalankan tugas salah satunya pada peningkatan jalan lingkungan agar mempermudah akses transportasi. Dalam hal ini kinerja tersebut dapat dikategorikan baik. Teori yang digunakan sebagai landasan dalam penilitian ini adalah pengukuran kinerja birokrasi publik. Di dalam pengukuran kinerja terdapat lima indikator yang digunakan menurut Dwiyanto yaitu I) Produktifitas, 2) Kualitas Layanan, 3) Responsivitas, 4) Responsibilitas dan 5) Akuntabilitas.

Penelitian ini menggunakan metode penelitian Kualitatif karena peneliti ingin memahami faktor sosiologis, situasi dan gejala atau fenomena sosial secara mendalam dan komprehensif. Teknik pengumpulan data melalui observasi, wawancara dan dokumentasi. Adapun data primer dalam penelitian ini adalah Kepala Bidang Kawasan Permukiman, Kepala Dinas Perumahan, Kawasan Permukiman dan Pertanahan Provinsi Kalimantan Tengah, dan masyarakat Kota Palangka Raya.

Berdasarkan hasil penelitian mengenai Kinerja Dinas Perumahan, Kawasan Permukiman, dan Pertanahan dalam Peningkatan Jalan Lingkungan di Kota Palangka Raya dalam hal ini kinerja tersebut dapat dikategorikan baik. Program kegiatan yang direncanakan dan dikerjakan sudah mencapai target yang diharapkan dalam hal mengurangi kawasan kumuh dan meningkatkan hunian yang layak khususnya permasalahan terhadap jalan lingkungan, walaupun tidak semua usulan yang datang langsung dari masyarakat dikerjakan namun semuanya tetap ditampung dan dipelajari oleh Disperkimtan.
\end{abstract}

Published

October 2020

\begin{abstract}
The Department of Housing, Residential and Land Area of Central Kalimantan Province carried out the duties of one of them on improving environmental roads to facilitate transportation access. In this case, such performance can be categorized well. The theory used as a cornerstone in this study is a measurement of the performance of the public bureaucracy. In the performance measurement there are five indicators used according to Dwiyanto namely I) Productivity, 2) Quality of Service, 3) Responsiveness, 4) Responsibility, and 5) Accountability.

This study uses qualitative research methods because researchers want to understand sociological factors, situations, and symptoms or social phenomena indepth and comprehensively. Data collection techniques through observation, interview, and documentation. The primary data in this study are the Head of Residential Area, Head of The Office of Housing, Residential, and Land Area of Central Kalimantan Province, and the people of Palangka Raya City.

Based on the results of research on the Performance of The Office of Housing, Residential Areas, and Land in Environmental Road Improvement in Palangka Raya City in this case the performance can be categorized as good. The program of activities planned and worked on has reached the expected target in terms of reducing slums and improving decent housing, especially the problems of environmental roads, although not all proposals that come directly from the community are done but all are still accommodated and studied by the Disperkimtan.
\end{abstract}




\section{PENDAHULUAN}

Indonesia merupakan salah satu negara yang memiliki penduduk sangat banyak sehingga perlu meningkatkan pembangunan nasional secara menyeluruh untuk menopang kesejahteraan penduduk Indonesia. Pembangunan nasional merupakan suatu usaha dalam meningkatkan kualitas masyarakat Indonesia dengan memanfaatkan kemajuan teknologi dan ilmu pengetahuan serta memperhatikan tantangan dalam perkembangan global. Dalam proses pembangunan nasional diperlukan peran pemerintah dan masyarakat agar fokus tercapainya pembangunan yang diharapkan khususnya pada bidang infrastruktur.

Permasalahan dalam bidang infrasruktur salah satunya adalah mengenai jalan, baik penyediaan maupun pengelolaan jalan sepenuhnya dilaksanakan oleh pemerintah, sebagai salah satu kewajibannya dalam penyediaan pelayanan publik. Undang-undang Nomor 38 Tahun 2004 tentang Jalan menyatakan, bahwa jalan sebagai salah satu prasarana transportasi penting dalam pengembangan kehidupan berbangsa dan bernegara, dalam pembinaan persatuan dan kesatuan bangsa. Jalan sebagai bagian sistem transportasi nasional yang mempunyai peranan penting terutama dalam mendukung bidang ekonomi, sosial dan budaya serta lingkungan dan dikembangkan melalui pendekatan pengembangan wilayah agar tercapai keseimbangan dan pemerataan pembangunan antardaerah, membentuk dan memperkukuh kesatuan nasional untuk memantapkan pertahanan dan keamanan nasional serta membentuk struktur ruang dalam rangka mewujudkan sasaran pembangunan nasional.

Namun pada setiap daerah masih sering kita temui jalan perkotaan maupun jalan perdesaan kondisinya rusak parah dan sangat sulit untuk dilalui, padahal jalan merupakan salah satu dari prasarana transportasi yang mempunyai fungsi vital dalam usaha pengembangan kehidupan masyarakat seperti yang tertuang dalam Undang-undang Nomor 38 Tahun 2004 tentang Jalan. Jalan juga mempunyai umur yang direncanakan dalam melayani lalu lintas yang melewatinya, sehingga seiring berjalannya waktu jalan akan mengalami penurunan kondisi yang juga akan berpengaruh terhadap menurunnya kemampuan jalan untuk melayani lalu lintas yang melewatinya. Hal ini akan menghambat kelancaran perjalanan dan otomatis fungsi dari jalan seperti dikemukakan di atas sulit dicapai.

Menurut Peraturan Pemerintah Nomor 34 Tahun 2006 tentang Jalan menyatakan bahwa jalan adalah prasarana transportasi darat yang meliputi segala bagian jalan, termasuk bangunan pelengkap dan perlengkapannya yang diperuntukkan bagi lalu lintas, yang berada pada permukaan tanah, di atas permukaan tanah, dibawah permukaan tanah/dan air, serta di atas permukaan air, kecuali jalan kereta api, jalan lori, dan jalan kabel.

Sebagai salah satu prasarana transportasi, kedudukan dan peranan jaringan jalan pada hakikatnya menyangkut hajat orang banyak. Untuk menjaga keberlanjutan dan kualitas layanan diperlukan pemeliharaan rutin jalan. Kualitas permukaan jalan akan memberikan dampak terhadap tingkat konsumsi bahan bakar, kebisingan, kenyamanan dalam berkendara dan keselamatan pengguna jalan.

Sebagai salah satu contohnya, jalan Marina Permai II merupakan jalan lingkungan yang pada awalnya merupakan jalan yang terdapat didalam sebuah Komplek Perumahan Marina Permai yang beralamat di jalan RTA milono km 6,4 Palangkaraya. Namun seiring berjalannya waktu jalan lingkungan di Komplek Marina Permai ini menjadi jalan utama yang menjadi penghubung antara komplek perumahan yang satu dengan komplek perumahan yang lainnya. Sehingga jalan ini menjadi salah satu pilihan yang banyak digunakan oleh masyarakat sekitar untuk mencapai tempat tujuan yang mereka inginkan. Namun pada kenyataannya jalan lingkungan ini masih dalam kondisi kurang baik, dimana terdapat jalan yang berlubang dan bergelombang, jalan yang permukaannya beraspal 
sudah terkelupas dan sebagian jalan lingkungan masih berupa tanah. Belum lagi jika masuk musim penghujan, jalan di komplek ini sebagian ada yang terendam air dan becek.

Dalam hal ini peran pemerintah sangat diperlukan dalam menangani persoalan jalan yang pada hakikatnya menyangkut orang banyak, sementara yang menjadi persoalan adalah keterbatasan dana pemeliharaan jalan yang tersedia dalam anggaran pemerintah. Keterbatasan biaya operasi dan pemeliharaan jalan merupakan masalah klasik yang dihadapi oleh negara-negara berkembang termasuk di Indonesia. Hal ini menyebabkan kegiatan pemeliharaan jalan tidak dapat berjalan sebagaimana mestinya, sehingga kondisi permukaan jalan banyak mengalami kerusakan.

Sesuai dengan Undang-undang Nomor I Tahun 2011 tentang Perumahan dan Kawasan Permukiman yang mengatakan bahwa Pemerintah perlu berperan dalam menyediakan dan memberikan kemudahan serta bantuan perumahan dan kawasan permukiman bagi masyarakat melalui penyelenggaraan perumahan dan kawasan permukiman yang berbasis kawasan serta keswadayaan masyarakat sehingga merupakan satu kesatuan fungsional dalam wujud tata ruang fisik, ekonomi, dan sosial budaya yang mampu menjamin kelestarian lingkungan hidup sejalan dengan semangat demokrasi, otonomi daerah, dan keterbukaan dalam tatanan kehidupan bermasyarakat, berbangsa dan bernegara.

Tujuan dalam penelitian ini adalah untuk mengetahui dan mendeskripsikan kinerja Dinas Perumahan, Kawasan Permukiman dan Pertanahan Provinsi Kalimantan Tengah dalam peningkatan jalan lingkungan di Kota Palangka Raya.

Menurut Delly Mustafa (20|4:122), kinerja bagi sebuah organisasi merupakan tolak ukur keberadaan organisasi itu sendiri. Artinya, semakin baik kinerja dari suatu organisasi, semakin baik pula keberadaannya, demikian pula sebaliknya.
Selanjutnya, Dwiyanto dalam Mustafa (2014:124), menjelaskan beberapa indikator yang digunakan untuk kinerja birokrasi publik yaitu :

I. Produktivitas, yaitu konsep produktivitas tidak hanya mengukur tingkat efisiensi tetapi juga efektifitas pelayanan, konsep ini pemahamannya terlalu sempit, sehingga GAO (General Accounting Office) mengembangkan satu ukuran produktivitas yang lebih luas dengan memasukkan seberapa besar pelayanan publik itu memiliki hasil yang diharapkan sebagai salah satu indikator kinerja yang penting.

2. Kualitas layanan, yaitu kinerja organisasi pelayanan publik sangat terkait dengan kualitas layanan. Dalam lingkungan birokrasi pemerintahan banyak pandangan negatif mengenai organisasi publik yang tidak memberikan kepuasan pelayanan kepada masyarakat.

3. Responsivitas, yaitu kemampuan organisasi untuk mengenali kebutuhan masyarakat, menyusun agenda dan prioritas pelayanan, dan mengembangkan program-program pelayanan publik sesuai dengan kebutuhan dan aspirasi masyarakat. Secara singkat responsivitas di sini menunjuk pada keselarasan antara program dan kegiatan pelayanan dengan kebutuhan dan aspirasi masyarakat.

4. Responsibilitas, yaitu menjelaskan apakah pelaksanaan kegiatan organisasi dilakukan sesuai dengan prinsip-prinsip administrasi yang benar dengan kebijakan organisasi, baik secara eksplisit maupun implisit.

5. Akuntabilitas, yaitu menunjuk pada seberapa besar kebijakan dan kegiatan organisasi publik tunduk pada pejabat politik yang dipilih oleh rakyat. Dalam konteks ini, konsep akuntabilitas publik dapat digunakan untuk melihat seberapa besar kebijakan organisasi publik konsisten dengan kehendak rakyat. 


\section{METODE PENELITIAN}

Menurut Sugiyono (2011:1), metode penelitian pada dasarnya merupakan cara ilmiah untuk mendapatkan data dengan tujuan dan kegunaan tertentu. Artinya dengan melalui penggunaan metode serta pemilihan sebuah metode yang tepat maka akan membantu jalannya sebuah penelitian. Berdasarkan pengertian metode penelitian diatas, maka metode yang digunakan peneliti dalam penelitian ini adalah metode Kualitatif. Menurut Sugiyono (201 I:14), "data kualitatif adalah data yang berbentuk kata, kalimat, skema, dan gambar".

Berdasarkan teori tersebut peneliti menggunakan metode kualitatif, hal ini dikarenakan untuk semakin memperkuat fakta-fakta yang di dapat oleh peneliti serta mengidentifikasi dan menjelaskan data yang ada secara sistematis dan dapat melihat fenomena-fenomena yang ada yakni tentang Kinerja Dinas Perumahan, Kawasan Permukiman dan Pertanahan Dalam Peningkatan Jalan Lingkungan di Kota Palangka Raya.

Teknik pengumpulan data merupakan langkah yang paling strategis dalam penelitian, karena tujuan utama dari penelitian adalah mendapatkan data. Teknik pengumpulan data yang digunakan dalam penelitian ini adalah dengan menggunakan metode observasi, wawancara, dan dokumentasi.

I. Observasi

Menurut Sutrisno Hadi dalam (Sugiyono, 2011:166), menyatakan bahwa "observasi merupakan suatu proses yang kompleks, suatu proses yang tersusun dari berbagai proses biologis dan psikologis. Dua di antara yang terpenting adalah proses-proses pengamatan dan ingatan". Pengumpulan data ini dilakukan untuk mengetahui secara langsung proses Kinerja Dinas Perumahan, Kawasan Permukiman dan Pertanahan Provinsi Kalimantan Tengah dalam Peningkatan Jalan Lingkungan di Kota Palangka Raya.

\section{Wawancara}

$$
\text { Menurut Sugiyono (2011:157), }
$$

wawancara adalah digunakan sebagai teknik pengumpulan data apabila peneliti ingin melakukan studi pendahuluan untuk menemukan permasalahan yang harus diteliti dan juga apabila peneliti ingin mengetahui hal-hal dari informan yang lebih mendalam dan jumlah informan sedikit atau kecil. Peneliti melakukan wawancara langsung dengan narasumbernya yaitu dengan Pihak Disperkimtan Provinsi Kalimantan Tengah khususnya pada Bidang Kawasan Permukiman yang terlibat langsung dalam peningkatan jalan lingkungan di Kota Palangka Raya, serta para warga masyarakat sekitar.

3. Dokumentasi

Pengumpulan data ini dilakukan dengan mencari data yang resmi dari pihak terkait yang dapat membantu proses penelitian seperti arsip, buku atau dokumen resmi lainnya.

Menurut Miles dan Huberman dalam (Sugiyono, 2014:334-343) mengemukakan bahwa "aktifitas dalam analisis data kualitatif dilakukan secara interaktif berlangsung secara terus menerus sampai tuntas sehingga datanya sudah jenuh. Aktifitas dalam analisis data yaitu reduksi data (data reduction), penyajian data (data display), dan menarik kesimpulan (conclusion drawing/verification)". Berdasarkan pernyataan diatas maka pengolahan data kualitatif dalam penelitian ini melalui tiga kegiatan analisis sebagai berikut :

I. Reduksi Data

Reduksi data adalah merangkum semua hal-hal pokok dan penting sesuai masalah penelitian yang diambil oleh peneliti. Dengan demikian data yang telah dirangkum atau direduksi akan memberikan sebuah gambaran yang lebih jelas serta mempermudah penelitian untuk melakukan pengumpulan data selanjutnya.

2. Penyajian Data 
Dalam penelitian data kualitatif, penyajian data bisa dilakukan dengan bentuk uraian singkat, bagan, serta hubungan antar kategori. Penyajian data sudah dilakukan, maka akan memudahkan peneliti untuk memahami apa yang terjadi.

3. Menarik Kesimpulan

Menarik kesimpulan dalam penelitian kualitatif dilakukan secara cermat dengan melakukan verifikasi beberapa tinjauan ulang pada catatan-catatan di lapangan sehingga data-data dapat diuji validasinya. Dalam melakukan penarikan kesimpulan, peneliti melihat dari rangkuman dan data yang telah disajikan dengan menggunakan tabel dan uraian singkat maka selanjutnya melakukan penarikan kesimpulan yang bertujuan untuk menjawab rumusan masalah mengenai bagaimana Kinerja Disperkimtan dalam Peningkatan Jalan Marina Permai II Kota Palangka Raya.

\section{HASIL DAN PEMBAHASAN}

Pentingnya Bidang Kawasan Permukiman tidak hanya untuk memberikan pemahaman kepada masyarakat terkait peningkatan jalan lingkungan, namun Bidang Kawasan Permukiman juga memberikan pemahaman kepada masyarakat terkait pemeliharaan jalan lingkungan dan drainase. Secara umum Kinerja Dinas Perumahan, Kawasan Permukiman dan Pertanahan Provinsi Kalimantan Tengah dalam Peningkatan Jalan Lingkungan di Kota Palangka Raya dapat dikategorikan Kurang Baik.

Berdasarkan hasil temuan peneliti mengenai program yang dikerjakan oleh Dinas Perumahan, Kawasan Permukiman dan Pertanahan Provinsi Kalimantan Tengah adalah Program kegiatan yang dijalankan berdasarkan Peraturan Gubernur Kalimantan Tengah Nomor 33 Tahun 2016 tentang Kedudukan, Satuan Organisasi, Tugas, Fungsi dan Tata Kerja Dinas Perumahan, Kawasan Permukiman dan Pertanahan Provinsi Kalimantan Tengah sebagaimana dimaksud untuk penjaminan terwujudnya rumah layak huni dan terjangkau dalam lingkungan yang sehat, aman, serasi, teratur, terencana, terpadu dan berkelanjutan namun masih terdapat banyak kekurangan.

Dapat di lihat dari data yang peneliti dapatkan bahwa program kerja Disperkimtan dari Tahun 20172019 sangat bervariasi. Mulai dari pengembangan infrastruktur perumahan dan permukiman perdesaan, pengembangan kawasan perumahan dan permukiman perkotaan, peningkatan jalan dan drainase, pengembangan atau peningkatan rumah bagi veteran dan janda pejuang, penataan dan penangan kawasan kumuh perkotaan serta peningkatan Rumah Layak Huni (RLH). Semua program yang dijalankan Disperkimtan merupakan bagian daripada penyiapan infrastruktur dasar bagi masyarakat dalam hal perumahan dan kawasan permukiman yang layak huni dimana penyediaan Prasarana, Sarana dan Utilitas Umum menjadi prioritas utama untuk dilaksanakan.

Kemudian peneliti juga mendapatkan data terkait data capaian target program kegiatan Disperkimtan dari tahun 2017-2019 terkait pembangunan jalan lingkungan dan drainase dengan hasil yang bervariasi. Tidak adanya target pasti yang menyesuaikan dengan total panjang jalan lingkungan kota palangka raya namun hal tersebut sudah masuk dalam capaian target yang diinginkan setiap tahunnya menyesuaikan dengan pagu anggaran yang disesuaikan dengan kebutuhan yang ada pada Disperkimtan.

Jika hal ini dicermati dari teori menurut Dwiyanto dalam Mustafa (2014:124), Responsivitas, yaitu kemampuan organisasi untuk mengenali kebutuhan masyarakat, menyusun agenda dan prioritas pelayanan, dan mengembangkan program-program pelayanan publik sesuai dengan kebutuhan dan aspirasi masyarakat. Secara singkat responsivitas di sini menunjuk pada keselarasan antara program dan kegiatan pelayanan dengan kebutuhan dan aspirasi masyarakat. Dalam hal ini bidang kawasan permukiman 
melakukan pelaksanaan program kegiatan pelayanan sesuai dengan pagu anggaran yang tersedia namun tetap memperhatikan kebutuhan dan aspirasi masyarakat dalam pekerjaan peningkatan jalan lingkungan di kawasan permukiman kota Palangka Raya. Terbuka dalam menerima setiap usulan dan akhirnya memproses jika ada laporan ataupun usulan dari masyarakat terkait jalan lingkungan mereka yang bermasalah. Dalam proses laporan atau pengajuan usulan ini melalui banyak tahapan proses yang bisa dipilih masyarakat, salah satu contohnya pengajuan usulan secara langsung dapat masyarakat lakukan dengan rapat bersama ketua RT dan membuat proposal kemudian disampaikan ke kelurahan atau kecamatan kemudian ke Gubernur dan diteruskan kepada Disperkimtan. Adapun masyarakat yang setelah membuat proposal langsung menyampaikan pengajuan usulan tersebut dengan datang langsung ke Disperkimtan atau melalui e-proposal yang terdapat pada website Disperkimtan.

Menurut Dwiyanto dalam Mustafa (20|4:124), Responsibilitas, yaitu menjelaskan apakah pelaksanaan kegiatan organisasi dilakukan sesuai dengan prinsip-prinsip administrasi yang benar dengan kebijakan organisasi, baik secara eksplisit maupun implisit. Berdasarkan hasil dari penelitian dan teori dalam hal ini penulis memaknai bahwa setiap penanganan terhadap pengajuan usulan masyarakat dalam peningkatan jalan maupun drainase di lingkungan kawasan permukiman sudah mengikuti sesuai kebijakan organisasi. Bidang kawasan permukiman khususnya, melakukan penanganan tersebut sesuai dengan pedoman pada Peraturan Gubernur Nomor 33 Tahun 2016 tentang Kedudukan, Satuan Organisasi, Tugas, Fungsi dan Tata Kerja Dinas Perumahan, Kawasan Permukiman dan Pertanahan Provinsi Kalimantan Tengah dan Undang-Undang Nomor 23 Tahun 2014 yang kemudian dirubah menjadi UU Nomor 9 Tahun 2015 tentang Pemerintahan Daerah. Di sisi lain dari hasil penelitian, masih banyaknya jalan lingkungan maupun drainase yang tidak layak dalam sebuah lingkungan kawasan permukiman. $\mathrm{Hal}$ ini bukan dikarenakan Pemerintah yang tidak menangani permasalahan tersebut, namun dikarenakan semua tahapan dan proses penataan, perbaikan maupun pemeliharaan infrastruktur selalu menyesuaikan dengan APBD yang tersedia setiap tahunnya sehingga setiap tahapan dan prosesnya selalu dikerjakan bertahap dan mendahulukan mana yang lebih darurat diperlukan masyarakat.

Dalam responsibilitas ini, bidang kawasan permukiman juga mengalami kendala dan hambatan seperti, tidak adanya wilayah kerja bagi pemerintah provinsi sehingga setiap pekerjaan yang bukan merupakan kewenangan pemerintah provinsi akan dilaksanakan menunggu hasil rapat dan pembahasan bersama pemerintah kabupaten kota. Contohnya seperti misalkan ada sebuah kawasan permukiman yang langsung mengajukan usulan perbaikan jalan lingkungan mereka kepada Disperkimtan, permasalahan tersebut hanya akan ditampung oleh Disperkimtan namun tetap dipelajari hingga akhirnya mendapatkan keputusan akan dihibahkan oleh pemerintah kabupaten kota kepada pemerintah provinsi atau tidak.

Menurut Dwiyanto dalam Mustafa (2014:124), mengenai Kualitas Layanan yaitu kinerja organisasi pelayanan publik sangat terkait dengan kualitas layanan. Dalam lingkungan birokrasi pemerintahan banyak pandangan negatif mengenai organisasi publik yang tidak memberikan kepuasan pelayanan kepada masyarakat. Yang dimaksud dengan kualitas layanan di sini terkait respon Disperkimtan terhadap segala laporan dan pengajuan usulan dari masyarakat terkait jalan lingkungan mereka yang bermasalah.

Selanjutnya untuk kualitas layanan yang diberikan oleh bidang kawasan permukiman dalam program kegiatan peningkatan jalan lingkungan dan drainase terbilang baik. Dari hasil wawancara peneliti sejauh ini, bidang kawasan permukiman melakukan semua tahapan proses dan pelaksanaan sesuai 
prosedur yang ada serta hasil di lapangan pun diterima dengan sangat baik oleh warga masyarakat sekitar. Warga merasa sangat puas dan banyak terbantu dengan peningkatan jalan yang dilakukan oleh Disperkimtan, terutama warga masyarakat lingkungan jalan marina permai II kota palangka raya.

Kemudian untuk sumber daya manusia yang dimiliki dalam melakukan aktifitas untuk mencapai tujuan organisasi sangat terstruktur, untuk bidang kawasan permukiman berjumlah 20 orang yaitu Kepala Bidang, Kepala Seksi Pendataan, Kepala Seksi Pencegahan dan Peningkatan Kualitas dan Kepala Seksi Preservasi Manfaat dan Pengendalian. 6 orang staf ahli dan 10 orang pegawai kontrak yang bertugas di bagian administrasi dan sebagian menjadi pengawas lapangan. Hal ini juga menjadi kendala dalam pelaksanaan tugas dan kegiatan, karena untuk sumber daya manusia dinilai masih kurang dibandingkan dengan banyaknya paket pekerjaan yang dikerjakan oleh Disperkimtan baik diperkotaan maupun diperdesaan.

Menurut Dwiyanto dalam Mustafa (20|4:|24),

Akuntabilitas yaitu menunjuk pada seberapa besar kebijakan dan kegiatan organisasi publik tunduk pada pejabat politik yang dipilih oleh rakyat. Dalam konteks ini, konsep akuntabilitas publik dapat digunakan untuk melihat seberapa besar kebijakan organisasi publik konsisten dengan kehendak rakyat. Yang artinya merupakan kewajiban bidang kawasan permukiman untuk mempertanggungjawabkan keberhasilan dan kegagalan dalam pelaksanaan misi organisasi untuk mencapai sasaran dan tujuan yang telah ditetapkan. Berdasarkan hasil yang peneliti peroleh bahwa Disperkimtan khususnya bidang kawasan permukiman adalah lembaga pemerintah yang diberi tanggung jawab dalam penyediaan fasilitasi pengelolaan prasarana, sarana, dan utilitas umum kawasan permukiman pada tingkat provinsi khususnya provinsi kalimantan tengah. Bidang kawasan permukiman tetap berusaha sebaik mungkin menjalankan seluruh tugas pokok dan fungsinya sesuai dengan Pergub Nomor 33 Tahun 2016.

Selanjutnya, Disperkimtan juga melakukan sosialisasi kepada masyarakat agar masyarakat dapat memahami bahwa pentingnya menjaga lingkungan, menciptakan hunian yang layak huni, mengurangi kawasan kumuh khususnya yang ada pada Provinsi Kalimantan Tengah. Namun pada kenyataannya dan diakui juga oleh pihak dinas bahwa kurangnya sosialisasi selama ini terhadap masyarakat terkait peningkatan jalan lingkungan dan drainase, sehingga kurangnya pemahaman masyarakat terhadap hal tersebut yang apabila dioptimalkan akan dapat menambah kualitas pelayanan dinas semakin baik demi tercapainya hunian yang layak huni dan mengurangi kawasan kumuh khususnya yang ada pada provinsi kalimantan tengah.

Menurut LAN-RI dalam Pasolong (201 I:I77), ada yang dinamakan masukan (inputs) adalah segala sesuatu yang dibutuhkan agar pelaksanaan kegiatan dapat berjalan untuk menghasilkan keluaran. Dalam hal ini bidang kawasan permukiman melakukan semua program kegiatan khususnya peningkatan jalan lingkungan agar dapat mengurangi kawasan kumuh yang ada di provinsi kalimantan tengah khususnya kota palangka raya. Bidang kawasan permukiman juga melakukan kegiatan keluaran (outputs) sosialisasi kepada masyarakat.

Menurut LAN-RI dalam Pasolong (201 I:I77), Manfaat (benefits) adalah sesuatu yang terkait dengan tujuan akhir dari pelaksanaan kegiatan. Indikator dampak (impacts) adalah pengaruh yang ditimbulkan baik positif maupun negatif pada setiap tingkatan indikator berdasarkan asumsi yang ditetapkan. Berdasarkan hasil penelitian di lapangan dan teori menunjukkan bahwa dari segi manfaat dan dampak yang ditimbulkan dari program kegiatan tersebut dapat dikategorikan kurang baik. Dikatakan kurang baik karena dalam hal ini bidang kawasan permukiman melakukan pelaksanaan program kegiatan pelayanan sesuai dengan pagu anggaran yang tersedia saja. Namun 
tetap menyesuaikan kebutuhan dan aspirasi masyarakat, walaupun tidak ada target khusus seperti yang seharusnya dalam pekerjaan peningkatan jalan lingkungan di kawasan permukiman kota Palangka Raya. Disperkimtan dapat menampung setiap laporan dan usulan namun tidak memiliki kewenangan khusus untuk langsung mengerjakannya dan akhirnya memproses jika ada laporan dan pengajuan usulan dari masyarakat terkait jalan lingkungan mereka yang bermasalah setelah mendapatkan instruksi pengerjaan berdasarkan pagu anggaran yang telah tersedia. Kemudian Disperkimtan juga memberikan sosialisasi terkait pemahaman masyarakat dalam menjaga dan memelihara prasarana, sarana dan utilitas umum yang sudah pemerintah sediakan. Selain itu agar masyarakat dapat memahami bahwa pentingnya menjaga lingkungan, menciptakan hunian yang layak huni, mengurangi kawasan kumuh di provinsi kalimantan tengah khususnya di kota palangka raya. Walaupun pada kenyataannya dan diakui juga oleh pihak dinas bahwa masih kurangnya sosialisasi selama ini terhadap masyarakat terkait peningkatan jalan lingkungan dan drainase, sehingga masyarakat masih kurang memahami terkait hal menjaga lingkungan, menciptakan hunian yang layak huni, mengurangi kawasan kumuh khususnya mengenai jalan lingkungan.

\section{KESIMPULAN}

Berdasarkan hasil penelitian dan pembahasan mengenai Kinerja Dinas Perumahan, Kawasan Permukiman, dan Pertanahan dalam Peningkatan Jalan Lingkungan di Kota Palangka Raya, dapat disimpulkan bahwa :

a. Dalam hal ini kinerja Disperkimtan tersebut dikategorikan kurang baik pada indikator kinerja responsibilitas dan produktivitas.

b. Responsibilitas dianggap kurang baik karena walaupun penanganan yang dilakukan oleh Disperkimtan sudah sesuai dengan pedoman pada Pergub Nomor 33 Tahun 2016 tentang
Kedudukan, Satuan Organisasi, Tugas, Fungsi dan Tata Kerja Dinas Perumahan, Kawasan Permukiman dan Pertanahan Provinsi Kalimantan Tengah, namun pada kenyataannya masih terkendala dengan pembagian wilayah kerja yang bukan menjadi kewenangan Disperkimtan, serta kurangnya sosialisasi kepada masyarakat dari pihak dinas terkait permasalahan tersebut.

c. Terkait Produktivitas program kegiatan yang direncanakan dan dikerjakan sudah mencapai target sesuai pagu anggaran yang tersedia dalam hal mengurangi kawasan kumuh dan meningkatkan hunian yang layak khususnya permasalahan terhadap jalan lingkungan. Untuk pekerjaan peningkatan jalan lingkungan di Kota Palangka Raya, Disperkimtan bersifat hanya membantu sehingga tidak memiliki kewenangan khusus dalam mengerjakan peningkatan jalan lingkungan untuk keseluruhan.

d. Kualitas layanan, sejauh ini bidang kawasan permukiman selalu menyambut baik setiap usulan pengajuan langsung dari masyarakat terkait permasalahan mengenai jalan lingkungan serta Disperkimtan melakukan sosialisasi terkait permasalahan perumahan dan kawasan permukiman yang dapat membantu masyarakat agar dapat lebih memahami bagaimana cara mendapatkan kawasan lingkungan yang layak huni, namun sosialisasi khusus terkait peningkatan jalan lingkungan masih sangat kurang disosialisasikan.

e. Terkait Responsivitas, bidang kawasan permukiman melakukan pelaksanaan program kegiatan yaitu berupa pelayanan yang sesuai dengan kebutuhan dan aspirasi masyarakat untuk mengurangi kawasan kumuh. Dalam responsivitas ini bidang kawasan permukiman juga mengalami kendala seperti kurangnya tenaga pengawas lapangan serta tidak dapatnya melaksanakan usulan langsung dari masyarakat dikarenakan memang tidak memiliki kewenangan langsung terhadap 
permasalahan tersebut terkecuali permasalahan yang berkaitan dengan bencana alam.

f. Selanjutnya terkait Akuntabilitas, Disperkimtan merupakan lembaga pemerintah yang diberi tanggung jawab dalam penyediaan fasilitasi pengelolaan prasarana, sarana, dan utilitas umum kawasan permukiman pada tingkat provinsi khususnya Provinsi Kalimantan Tengah.

\section{SARAN}

Peneliti ingin memberikan saran sebagai bahan pertimbangan bagi Dinas Perumahan, Kawasan Permukiman dan Pertanahan Provinsi Kalimantan Tengah yaitu sebagai berikut :

I. Dinas Perumahan, Kawasan Permukiman dan Pertanahan Provinsi Kalimantan tengah khususnya Bidang Kawasan Permukiman harus melakukan sosialisasi secara rutin kepada masyarakat terutama masyarakat yang ekonominya dibawah rata-rata dalam memberikan edukasi terkait pemahaman kawasan permukiman. Bagaimana cara menciptakan kawasan permukiman yang layak dan lingkungan yang tetap terjaga di tengah-tengah pembangunan infrastruktur yang akan terus berlangsung demi tercapainya tujuan pembangunan daerah yang diharapkan.

2. Pentingnya bagi Disperkimtan untuk memiliki data sendiri terkait Jalan Lingkungan di Kota Palangka Raya terlepas dari tupoksinya yang hanya membantu pekerjaan dari Pemerintah Kota dalam hal peningkatan jalan lingkungan, sehingga dapat memudahkan masyarakat dalam memperoleh informasi terkait data yang diinginkan.

3. Penambahan sumber daya manusia mungkin perlu dipertimbangkan kembali agar dalam melakukan pengawasan setiap pekerjaan dapat terlaksana dengan lebih maksimal dengan hasil yang memuaskan bagi segala pihak.

\section{DAFTAR PUSTAKA}

Anggara, Sahaya. 2016. Ilmu Administrasi Negara. CV Pustaka Setia. Jawa Barat.

Pasolong, Harbani. 20II. Teori Administrasi Publik. ALFABETA. Bandung.

Sugiyono. 2011. Metode Penelitian Administrasi dilengkapi dengan metode R\&D. ALFABETA. Bandung.

Hardiyansyah. 20II. Kualitas Pelayanan Publik. Gava Media. Yogyakarta.

Neuman, W.L. 2013. Metodologi Penelitian Sosial : Pendekatan Kualitatif dan Kuantitatif. Hak Cipta Bahasa Indonesia. PT Indeks. Bandung.

Mustafa, Delly. 2014. Birokrasi Pemerintahan. ALFABETA. Bandung.

Peraturan Pemerintah Nomor 34 Tahun 2006. Jalan.

Peraturan Gubernur Nomor 33 Tahun 2016. Kedudukan, Susunan Organisasi, Tugas, Fungsi dan Tata Kerja Dinas Perumahan, Kawasan Permukiman dan Pertanahan Provinsi Kalimantan Tengah.

Renstra 2016-2021 Dinas Perumahan, Kawasan Permukiman dan Pertanahan Provinsi Kalimantan Tengah.

Siagian, P Sondang. 2009. Kiat Meningkatkan Produktifitas Kerja. Rineka Cipta. Jakarta.

Torang, Syamsir. 2013. Organisasi dan Manajemen. ALFABETA. Bandung.

Undang-Undang Republik Indonesia Nomor 38 Tahun 2004. Jalan.

Undang-Undang Republik Indonesia Nomor I Tahun 20I I. Perumahan dan Kawasan Permukiman.

Undang-Undang Republik Indonesia Nomor 23 Tahun 2014. Pemerintahan Daerah.

Undang-Undang Republik Indonesia Nomor 9 Tahun 2015. Pemerintahan Daerah.

Wirawan. 2009. Evaluasi Kinerja Sumber Daya Manusia. Salemba Empat. Jakarta. 